\title{
PHYTOCHEMICAL STUDIES AND ANTIMICROBIAL COMPOUNDS FROM FRUIT OF THESPESIA POPULNEA (L) SOLAND EX CORREA
}

\author{
USHA NANDHINI S*, RADHIKA V, MANISHA S, ANUSHA Jeslin V
}

Department of Biotechnology, Sathyabama University, Chennai, Tamil Nadu, India. Email: missusha@yahoo.com

Received: 24 December 2016, Revised and Accepted: 13 January 2017

\author{
ABSTRACT \\ Objectives: To study the phytochemical analysis and antimicrobial compounds from fruits of Thespesia populnea.
}

Methods: The determination of antimicrobial activity of fruit extract was done by agar well diffusion method. Active compounds were extracted by different solvent extraction methods. The presence of active compounds was confirmed by ultraviolet-visible spectrophotometry, Fourier transform infrared spectroscopy and gas chromatography-mass spectrometry analysis (GC-MS).

Results: The active extract was identified by the GC-MS analysis and it was revealed that the presence of oleic acid, pentadecanoic acid, and N-hexadecanoic acid.

Conclusion: This method adopted and extracted purified active metabolites and can be fruitfully employed for obtaining novel antibiotic compounds to treat human pathogenic bacterial and fungal diseases.

Keywords: Thespesia populnea (L.), Gas chromatography-mass spectrometry, Fourier transform infrared spectroscopy, Antimicrobial, Phytochemical.

(C) 2017 The Authors. Published by Innovare Academic Sciences Pvt Ltd. This is an open access article under the CC BY license (http://creativecommons. org/licenses/by/4. 0/) DOI: http://dx.doi.org/10.22159/ajpcr.2017.v10i4.16759

\section{INTRODUCTION}

Thespesia populnea is a large tree belongs to the family Malvaceae, found in tropical and coastal regions of India. The tree grows to a height of $15 \mathrm{~m}$ and its leaves are simple and heart shaped with a distinct tip. Flowers are bisexual and yellow in color. Fruits are brown in color with too many capsules. The tree yields valuable dark red wood and also an oil from its seeds. The tree is able to grow in a wide range of soil pH (6-7.5) in the coastal environments.

Various parts of the plants are found to possess useful medicinal properties. The leaves are applied locally in swollen joints for their anti-inflammatory effects and also for skin diseases, hepatitis, jaundice, ulcers, wounds, psoriasis, scabies, and urinary tract infections. The other diseases such as diabetes, cholera, cough, asthma, and guinea worm infections [1]. The fruits of the plant are used in Ayurveda for the control of diabetes [2]. The barks and flowers possess astringent, hepatoprotective, and antioxidant activity [3]. Therapeutically active principles are extracted from all parts of the plant body, but the concentration of these components varies from part to part. Normally, parts known to contain the highest concentration of the principles are preferred to therapeutic purposes and it can either be the leaves, stems, barks, roots, bulks, corms, rhizomes, woods, flowers, fruits or the seeds [4].

Many medicinal plants possess diverse active principles and are useful as curative in various human and animal diseases. The continuing use of herbs in medicine reveals that the functional value and its necessity in the future. In modern medicine, the importance of medicinal plants is increasing with pharmaceutical and cosmetic industries and progressively uses more plant sources of rural or untainted areas [5].

Four naturally occurring quinines are thespone, thespesone, mansonone-D, and mansonone-H have been extracted from heart wood of T. populnea. The phytochemical study of bark of this plant reveals that the presence of gossypol, tannin, acacetin, quercetin, coloring matter, and leaf extract indicates the presence of lupeol, lupenone, $\beta$-sitosterol [6]. The flowers of the same plant contained kaempferol, kaemperol-7-glucoside and gossypetin. The fruit kernels of this plant were reported to contain $\beta$-sitosterol, ceryl alcohol and a yellow pigment, thespesin [7].

The aim of this study was to evaluate the antimicrobial activity of dichloromethane, ethyl acetate, ethanol, and aqueous extracts of T. populnea fruits against bacterial and fungal strains of medical importance.

\section{METHODS}

Collection and processing of sample

Fruits part of T. populnea were collected from Sathyabama University, Chennai, situated in the state of Tamil Nadu (PARC/2017/3333 by Professor P. Jayaraman). The healthy plant materials like fruits were washed with running tap water followed with $0.1 \%$ of sodium hypochlorite solution simultaneously and sterile distilled water for about 5 minutes. After washing the healthy plant parts are shade dried for 2 weeks and pulverized to coarse powder using electric mixer grinder. The powder was then sieved to yield particle size of 50-150 mm and stored in airtight bottles for further studies [8].

\section{Compound extraction}

The dried fruit powder was subjected to extraction using $250 \mathrm{ml}$ of solvents in the increasing order of polarity (dichloromethane, ethanol, ethyl acetate, and water). Powders with solvent kept in a Soxhlet extractor for $72 \mathrm{hrs}$. The aqueous extract was prepared by maceration with distilled water for $24 \mathrm{hrs}$. The extracts were stored in airtight containers in refrigerator below $10^{\circ} \mathrm{C}$ for further use [9].

Phytochemical characterization of extracts

The ethanol, ethyl acetate, and aqueous fruit extracts of T. populnea were used for qualitative phytochemical analysis. Phytochemicals such as carbohydrates, proteins, flavonoids, tannins, phytosterols, glycosides, saponins, phenols, terpenoids, and alkaloids were analyzed according to the standard method [10]. 
Antibacterial and antifungal activity

Antibacterial and antifungal assay was carried out by agar well diffusion method [11] and it was evaluated by measuring the zone of inhibition. Four different solvent extracts were tested against selected bacterial and fungal strains. The test cultures were evenly spread over on agar plates using a sterile cotton swab. The sterile wells were filled with $100 \mu \mathrm{l}$ of solvent extract solution. Bacterial test plates were incubated at $37^{\circ} \mathrm{C}$ for $24 \mathrm{hrs}$ and fungal plates were incubated at $28^{\circ} \mathrm{C}$ for $72 \mathrm{hrs}$ and the zones of inhibition were subsequently measured in $\mathrm{mm}$. Ciprofloxacin $(5 \mu \mathrm{g} / \mathrm{ml})$ and amphotericin B $(10 \mu \mathrm{g} / \mathrm{ml})$ was used as a positive control and respective solvents served as negative control [12].

\section{Identification of active compounds}

The presence of active compounds was identified using ultravioletvisible spectrophotometry in the range from $200 \mathrm{~nm}$ to $400 \mathrm{~nm}$. Fourier transform infrared spectroscopy used to determine the groups of compound in the spectral range of $4000-50 \mathrm{~cm}^{-1}$. Gas chromatographymass spectrometry (GC-MS) method used to identify chemical compounds present in the fruit extract $[13,14]$.

\section{RESULTS AND DISCUSSION}

The collected plant was identified by Plant Anatomy Research Center in Chennai named as T. populnea (L.) soland. ex correa and the serial number was PARC/2017/3333 by Professor P. Jayaraman. After the successful processing of the sample and hot Soxhlet extraction of the fruit extract in investigation, the preliminary phytochemical study revealed that ethanol, ethylacetate and aqueous extract of T. populnea (L.) contains carbohydrates, proteins, flavonoides, tannins, glycosides, phenols, terpenoids, and alkaloids. Phytosterols and saponins were absent in the extract shown in Table 1. Phytochemical analysis of $T$. populnea methanolic leaves extract has reported as the presence of flavonoides, tannins, steroids, glycosides, saponins, phenols, terpenoids, and alkaloids [15].

\section{Antibacterial and antifungal activity}

The zone of inhibition obtained with different solvent fruit extracts of T. populnea shown in Table 2. Ethyl acetate extracts were found to be having significant antibacterial activity against Escherichia coli, Staphylococcus aureus, and Pseudomonas aeruginosa. Ethanolic and aqueous extracts were found to be moderate and dichloromethane found to be mild antibacterial activity. Ethanolic fruit extracts were showed significant antifungal activity against Aspergillus niger and ethylacetate extracts were showed against Aspergillus flavus Table 3. As per [16] antimicrobial activity of fruit extracts of T. populnea was tested against organism S. aureus, E. coli, Bacillus subtilis, Pseudomonas aeruginosa, A. niger, A. flavus, Candida albicans, and Salmonella typhi.

\section{Identification of active compounds}

The ethanolic fruit extracts were showed peak at $317 \mathrm{~nm}$ in ultraviolet-visible spectrophotometry. It indicated that the presence of active compounds in the extracts. The functional groups present in the ethanolic extracts of fruit were identified by Fourier transform infrared spectroscopy (Table 4 and Fig. 1). The compounds present in the ethanolic fruit extract of $T$. populnea were identified by GC-MS analysis. The active principles with their retention time, molecular formula, molecular weight, and peak area in percentage are presented in Table 5. The result revealed that the presence of 17 major compounds (Fig. 2). Similar observation was reported [17] in which the phytoconstituent rich ethanolic extract of Maranta arundinacea (L.) subjected to GC-MS analysis revealed the presence of 49 compounds. The results of the GCMS analysis provide 17 major peaks determining the presence of phytochemical compounds with different therapeutic activities.

\section{CONCLUSION}

In conclusion, the results of this study revealed that ethyl acetate and ethanol extracts of $T$. populnea fruits exhibited strong antimicrobial

Table 1: Phytochemical screening of fruit extract

\begin{tabular}{llll}
\hline S.N & Phytoconstituents & Ethanol & Ethyl acetate \\
\hline 1 & Carbohydrates & + & + \\
2 & Proteins & + & + \\
3 & Flavonoids & + & + \\
4 & Tannins & + & + \\
5 & Phytosterols & + & - \\
6 & Glycosides & + & + \\
7 & Saponins & + & + \\
8 & Phenols & + & + \\
9 & Terpenoids & + & + \\
10 & Alkaloids & + & + \\
\end{tabular}

-= absence, $+=$ presence

Table 2: Antibacterial activity of fruit extract $(100 \mu \mathrm{g} / \mathrm{ml})$ of $T$. populnea

\begin{tabular}{|c|c|c|c|c|c|c|}
\hline \multirow[t]{2}{*}{ S.N } & \multirow[t]{2}{*}{ Test organisms } & \multicolumn{5}{|c|}{ Zone of inhibition (mm) } \\
\hline & & Dichloromethane & Ethanol & Ethyl acetate & Aqueous & Ciprofloxacin $(5 \mu \mathrm{g} / \mathrm{ml})$ \\
\hline 1 & E. coli & $8.5 \pm 0.50$ & $12.5 \pm 0.50$ & $12.8 \pm 0.75$ & $11.5 \pm 0.50$ & $15.5 \pm 0.50$ \\
\hline 3 & P. aeruginosa & $10.8 \pm 0.75$ & $8.5 \pm 0.50$ & $11.5 \pm 0.50$ & $8.5 \pm 0.50$ & $12.5 \pm 0.50$ \\
\hline
\end{tabular}

E. coli: Escherichia coli, S. aureus: Staphylococcus aureus, P. aeruginosa: Pseudomonas aeruginosa, T. populnea: Thespesia populnea

Table 3: Antifungal activity of fruit extract $(100 \mu \mathrm{g} / \mathrm{ml})$ of $T$. populnea

\begin{tabular}{|c|c|c|c|c|c|c|}
\hline \multirow[t]{2}{*}{ S.N } & \multirow[t]{2}{*}{ Test organisms } & \multicolumn{5}{|c|}{ Zone of inhibition (mm) } \\
\hline & & Dichloromethane & Ethanol & Ethyl acetate & Aqueous & Amphotericin B $(10 \mu \mathrm{g} / \mathrm{ml})$ \\
\hline 1 & A. niger & $11.5 \pm 0.50$ & $12.8 \pm 0.76$ & $10.5 \pm 0.50$ & $8.5 \pm 0.50$ & $20.5 \pm 0.50$ \\
\hline 2 & A. flavus & $10.5 \pm 0.50$ & $11.8 \pm 0.76$ & $13.5 \pm 0.50$ & $10.5 \pm 0.50$ & $18.5 \pm 0.50$ \\
\hline
\end{tabular}

A. niger: Aspergillus niger, A. flavus: Aspergillus flavus, T. populnea: Thespesia populnea 


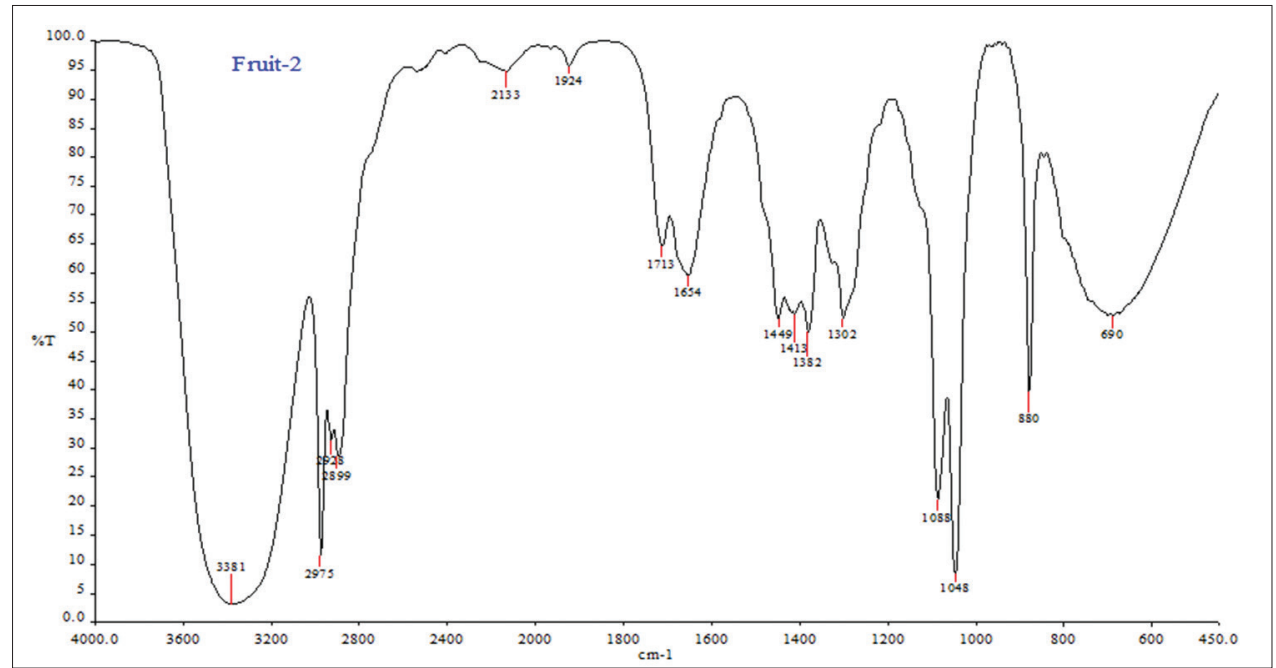

Fig. 1: Fourier transform infrared spectroscopy analysis of ethanolic fruit extract

Table 4: Fourier transform infrared spectroscopy analysis of fruit extract

\begin{tabular}{lll}
\hline Bond & Functional groups & ${\text { Frequency range } / \mathbf{c m}^{-1}}^{-1048}$ \\
\hline $\mathrm{C}=\mathrm{O}$ & Alcohols, ethers, carboxylic acid, esters & 1048 \\
$\mathrm{C}=\mathrm{O}$ & Alcohols, ethers, carboxylic acid, esters & 1088 \\
$\mathrm{C}-\mathrm{H}$ & Alkenes & 1382 \\
$\mathrm{O}-\mathrm{H}$ & Carboxylic acids & 2728 \\
$\mathrm{C}-\mathrm{H}$ & Alkanes & 2899 \\
$\mathrm{O}-\mathrm{H}$ & Carboxylic acids & 2975 \\
$\mathrm{~N}-\mathrm{H}$ & Amines & 3381 \\
\hline
\end{tabular}

Table 5: Antimicrobial compounds identified in T. populnea by GC-MS analysis

\begin{tabular}{|c|c|c|c|c|c|c|}
\hline Peak No & $\begin{array}{l}\text { Retention } \\
\text { time }\end{array}$ & Name of the compound & $\begin{array}{l}\text { Molecular } \\
\text { formula }\end{array}$ & $\begin{array}{l}\text { Mol. } \\
\text { wt. }\end{array}$ & Area\% & Activity \\
\hline 1 & 4.7 & Oxime-methoxy-phenyl & $\mathrm{C}_{8} \mathrm{H}_{9} \mathrm{NO}_{2}$ & 151 & 0.75 & Antimicrobial \\
\hline 2 & 6.38 & Monoethyl malonate monoamide & $\mathrm{C}_{5}^{0} \mathrm{H}_{9} \mathrm{O}_{3} \mathrm{~N}$ & 131 & 0.68 & Antibacterial \\
\hline 3 & 8.37 & $\begin{array}{l}\text { Ethanol, 2-\{5,6-dimethyl benzimidazol, } \\
\text { 2-ethylthio }\}\end{array}$ & $\mathrm{C}_{9}^{3} \mathrm{H}_{9} \mathrm{NS}_{2}^{3}$ & 195 & 4.50 & Antimicrobial and anti-inflammatory \\
\hline 4 & 9.37 & Tetradecanoic acid & $\mathrm{C}_{14} \mathrm{H}_{28} \mathrm{O}_{2}$ & 228 & 1.56 & Larvicidal [18] and antimicrobial [19] \\
\hline 5 & 14.4 & Pentadecanoic acid & $\mathrm{C}_{15}^{14} \mathrm{H}_{30} \mathrm{O}_{2}$ & 242 & 5.50 & Antimicrobial \\
\hline 6 & 14.85 & Pentadecanoic acid, 13 methyl, methylester & $\mathrm{C}_{17}^{15} \mathrm{H}_{34}^{30} \mathrm{O}_{2}^{2}$ & 270 & 1.92 & Antifungal \\
\hline 7 & 15.73 & N-hexadecanoic acid & $\mathrm{CH}_{16} \mathrm{H}_{32} \mathrm{O}_{2}$ & 256 & 1.32 & $\begin{array}{l}\text { Antimicrobial, anti-inflammatory [20], } \\
\text { antioxidant, hypocholesterolemic } \\
\text { nematicide, pesticide, 5-alpha } \\
\text { reductase inhibitor [21], potent } \\
\text { mosquito larvicide [22] }\end{array}$ \\
\hline 8 & 16.43 & 16-octadecanoic acid, 9-methyl, methyl ester & $\mathrm{C}_{19} \mathrm{H}_{36} \mathrm{O}_{2}$ & 296 & 2.48 & Antimicrobial \\
\hline 9 & 17.1 & Heptadecanoic acid, 16-methyl, methyl ester & $\mathrm{C}_{19}^{19} \mathrm{H}_{38}^{36} \mathrm{O}_{2}^{2}$ & 298 & 2.46 & Antimicrobial \\
\hline 10 & 17.88 & Octadecanoic acid & $\mathrm{C}_{18}^{19} \mathrm{H}_{36} \mathrm{O}_{2}$ & 284 & 4.82 & $\begin{array}{l}\text { Antimicrobial and } \\
\text { anti-inflamatory [23] }\end{array}$ \\
\hline 11 & 18.33 & $\begin{array}{l}\text { 6-methyl-5-oxo011-propenyl, 12, } \\
\text { 13-dioxa-tricyclo(,3,1,0!1,6)) tridecane, } \\
\text { 8-carboxylic acid }\end{array}$ & $\mathrm{C}_{12} \mathrm{H}_{18} \mathrm{O}_{4}$ & 226 & 2.40 & Antibacterial \\
\hline 12 & 19.07 & $\begin{array}{l}\text { 4-piperideneethanol, a-ethyl, } \\
\text { 1-(2-indole-3-yethyl) }\end{array}$ & $\mathrm{C}_{9} \mathrm{H}_{19} \mathrm{NO}_{3} \mathrm{~S}$ & 221 & 2.38 & Antimicrobial \\
\hline 13 & 19.55 & Oleic acid & $\mathrm{C}_{18} \mathrm{H}_{34} \mathrm{O}_{2}$ & 282 & 3.85 & Antibacterial [24] \\
\hline 14 & 18.72 & Methyl salicylate & $\mathrm{C}_{8} \mathrm{H}_{8} \mathrm{O}_{3}$ & 152 & 3.82 & Antimicrobial \\
\hline 15 & 21.03 & 5-amino3-propyl salicylic acid & $\mathrm{C}_{7}^{8} \mathrm{H}_{7}^{8} \mathrm{NO}_{3}^{3}$ & 153 & 2.21 & Antifungal \\
\hline 16 & 21.6 & Benzoic acid, 2-hydroxy, ethyl ether & $\mathrm{C}_{9} \mathrm{H}_{10} \mathrm{O}_{3}$ & 166 & 2.08 & Antimicrobial \\
\hline 17 & 23.22 & $\begin{array}{l}\text { 1,2-benzene dicarboxlic acid, } \\
\text { mono (2-ethylhexyl) ester }\end{array}$ & $\mathrm{C}_{16} \mathrm{H}_{22} \mathrm{O}_{4}$ & 278 & 1.56 & Anticancer \\
\hline
\end{tabular}

GC-MS: Gas chromatography-mass spectrometry, T. populnea: Thespesia populnea

activity against bacterial and fungal strains tested. The inhibitory effect of this plant will be helpful to pharmacological industry to prepare antimicrobial drugs for treating various bacterial and fungal diseases. 


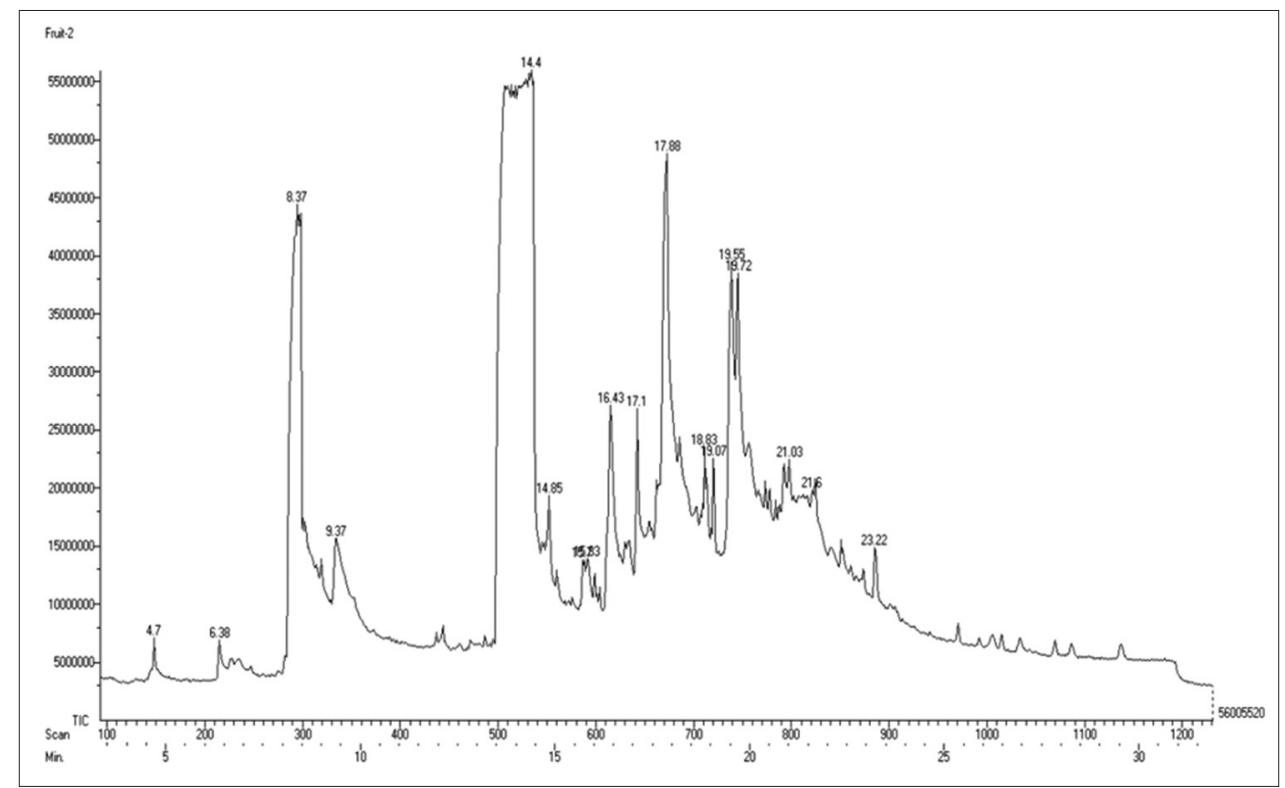

Fig. 2: Gas chromatography-mass spectrometry analysis of fruit extract

\section{ACKNOWLEDGMENT}

The authors wish to thank Sathyabama University, Chennai, for providing lab facilities and provided pathogenic microorganisms for this study.

\section{REFERENCES}

1. Anonymous. The Wealth of India. New Delhi: Publication and Information Directorate (CSIR); 1995.

2. Satyanarayana T, Saritha T, Balaji M, Ramesh A, Boini MK. Antihyperglycemic and hypoglycemic effects of Theapesia populnea fruits in normal and alloxan induced diabetes in rabbits. Saudi Pharm J 2004; $12: 107-11$

3. Ilavarasan R, Vasudevan M, Anbazhagan S, Venkataraman S. Antioxidant activity of Theapesia populnea bark extracts against carbon tetra chloride - Induced liver injury in rats. J Ethnopharmacol 2003;87(2-3):227-30.

4. Kafaru E. Immense Help from Natives Workshop. $1^{\text {st }}$ ed. Lagos, Nigeria: Elizabeth Kafaru; 1994.

5. Chescu DI, Dumitriu IF. Practical Biochemistry. Bucharest: University of Bucharest Publishing House; 1998. p. 105.

6. Parthasarathy R, Ilavarsan R, Karrunakaran CM. Antidiabetic activity of Thespesia populnea bark and leaf extract against streptozotocin induced diabetic rats. Int J Pharm Tech Res 2009;1(4):106-9.

7. Ghosh K, Bhattacharya TK. Preliminary study on the anti-implantation activity of compounds from the extracts of seeds of Thespesia populnea. Indian J Pharmacol 2004;36(5):288-91.

8. Moon A, Khan A, Wadher B. Antibacterial potential of Thespesia populnea (Linn.) Sol. Ex Corr. Leaves and its corresponding and drug resistant isolates. Indian J Nat Prod Resour 2010;1(4):444-9.

9. Moon AN, Khan A, Wadher BJ. Evaluation of phytochemical and antibacterial properties of medicinal plants. J Curr Sci 2006;9(1):219-26.

10. Harborne JB. Phytochemical Methods: A Guide to Modern Technique of Plant Analysis. London: Chapman and Hall; 1973. p. 271.

11. Nandhini SU, Sangareshwari S, Lata K. Gas chromatography-mass spectrometry analysis of bioactive constituents from the marine Streptomyces. Asian J Pharm Clin Res 2015;8(2):244-6.
12. Shekshavali T, Hugar S. Antimicrobial activity of Thespesia populnea Soland. Ex Correa bark extracts. Indian J Nat Prod Resour 2012;3(1):128-30

13. Rao KP. Phytochemical screening and antioxidant potential of Thespesia populnea (L.) Seed extract. Der Pharm Lett 2016;8(12):200-7.

14. Nandhini SU, Selvam MM. Bioactive compounds produced by Streptomyces strain. Int J Pharm Pharm Sci 2013;4 Suppl 1:176-8.

15. Krishnamoorthy S, Raj GA, Chandrasekaran M. Antibacterial and antifungal activity of leaves of Thespesia populnea. Int J Pharm Pharm Sci 2014;6(8):404-11.

16. Siju EN, Shirwaikar A, Devi S. Antimicrobial activity of fruit extracts of Thespesia populnea. Adv Pharmacol Toxicol 2011;12(3):79-82

17. Nishaa S, Vishnupriya M, Sasikumar JM, Gopalakrishnan VK. Phytochemical screening and GC-MS analysis of ethanolic extract of rhizomes of Maranta arundinacea L. Res J Pharm Biol Chem Sci 2013;4(2):52-9.

18. Sivakumar R, Jebanesan A, Govindarajan M, Rajasekar P. Larvicidal and repellent activity of tetradecanoic acid against Aedes aegypti (Linn.) And Culex quinquefasciatus (Say.) (Diptera: Culicidae). Asian Pac J Trop Med 2011;4(9):706-10.

19. Gritto MJ, Nandagopalan V, Doss A. GC-MS analysis of bioactive compounds in methanolic extract of Thespesia populnea (L.) Sol. Ex Correa. World J Pharm Pharm Sci 2015;4(12):498-504.

20. Aparna V, Dileep KV, Mandal PK, Karthe P, Sadasivan C, Haridas M. Anti-inflammatory property of n-hexadecanoic acid: Structural evidence and kinetic assessment. Chem Biol Drug Des 2012;80(3):434-9.

21. Kumar PP, Kumaravel S, Lalitha C. Screening of antioxidant activity, total phenolics and GC-MS study of Vitex negundo. Afr J Biochem Res 2010;4:191-5

22. Rahuman AA, Gopalakrishnan G, Ghouse BS, Arumugam S, Himalayan B. Effect of Feronia limonia on mosquito larvae. Fitoterapia 2000;71(5):553-5.

23. Rajamurugan R, Shilpa GR, Kumaravel S, Paranthaman R. GC-MS analysis, antioxidant and antibacterial activities of Thespesia populnea Linn. Leaf - In vitro study. BioMedRx 2013;1(3):248-53.

24. Awa EP, Ibrahim S, Ameh DA. GC/MS analysis and antimicrobial activity of diethyl ether fraction of methanolic extract from the stem bark of Annona senegalensis Pers. Int J Pharm Sci Res 2012;3(11):4213-8. 